\title{
Knowledge, Attitude and Practice about Hepatitis B, Hepatitis C and Human Immunodeficiency Virus among Barbers of Sylhet, Bangladesh
}

\author{
Madhusudan Saha*1, Md Jahangir Alam², Mostak Uddin Ahmed ${ }^{3}$, Md Anisur Rahman ${ }^{4}$, \\ Malay Kumar Sur Chowdhury ${ }^{5}$, Muhammd Oliur Rahman ${ }^{6}$, Syed Alamgir Safwath ${ }^{7}$
}

\begin{abstract}
Introduction:This study was designed to see the knowledge, attitude and practice of barbers regarding transmission of hepatitis B, C and HIV viral infections. Materials and Methods: Barbers from Sylhet were interviewed with a predesigned questionnaire. Positive answers for blood transfusion, syringe sharing, use of contaminated shaving instruments and unsafe sex as way of transmission were taken as correct. Statistical analysis was done using SPSS 20 version. Result: Total 403 barbers, age from 14 years to 69 years (mean 27.11) were interviewed. In this group 232 (57.6\%) had education illiterate to class five level. Among them $245(60.3 \%)$ had income below 10 thousand per month. Blood transfusion could transmit $H B V, H C V$ and HIV was known to $136(33.7 \%), 129(32.00 \%)$ and $247(61.30 \%)$, contaminated syringe sharing could transmit HBV, HCV and HIV respectively was known to 131 (32.5\%), $127(31.50 \%)$ and 278 (69.0\%) barbers, unsafe sex could transmit HBV, HCV and HIV was known to $166(41.2 \%), 158(39.2 \%)$ and 317 (78.70\%) barbers respectively and Contaminated shaving instruments could transmit HBV, HCV and HIV was known to 101 (25.1\%), 96 (23.8\%) and 156 (38.7\%) barbers respectively. In this series 84 (20.84\%) barbers answered correctly. This answers differed significantly within different level of education. Their knowledge of sterilization of shaving instruments was poor. Conclusion: Knowledge of our barbers regarding transmission of $\mathrm{HBV}, \mathrm{HCV}$ and HIV and sterilisatioin of shaving instruments are inadequate. Institutional education and structured professional training may improve their services and decrease transmission of blood borne viral diseases.
\end{abstract}

Keywords: Knowledge of barbers, Transmission of Hepatitis B, C and HIV.

Number of Tables: 05; Number of References: 24; Number of Correspondence: 03.

*1. Corresponding Author:

Dr. Madhusudan Saha MBBS MD

Professor

Department of Gastroenterology

North East Medical College

South Surma, Sylhet.

Email: madhunibedita@gmail.com

Mobile No. +8801711367847

2. Dr. Md Jahangir Alam MBBS MCPS MD

Associate Professor

Department of Gastroenterology

Sylhet MAG Osmani Medical College, Sylhet.

3. Dr. Mostak Uddin Ahmed MBBS FCPS MD

Associate Professor

Department of Gastroenterology

Sylhet MAG Osmani Medical College, Sylhet.

4. Dr. Md Anisur Rahman MBBS DEM

Assitant Professor

Department of Medicine

North East Medical College, South Surma, Sylhet.

5. Dr. Malay Kumar Sur Chowdhury MBBS MD Associate Professor

Department of Gastroenterology

Sylhet MAG Osmani Medical College, Sylhet.

6. Dr. Muhammd Oliur Rahman, MBBS FCPS MD

Associate Professor

Department of Gastroenterology

Sylhet MAG Osmani Medical College, Sylhet.

7. Dr. Syed Alamgir Safwath MBBS MCPS MD

Professor

Department of Gastroenterology

Jalalabad Ragib Rabeya Medical College, Sylhet.

\section{Introduction}

Hepatitis B (HBV) is one of the most common infectious disease in the world causing significant morbidity and mortality ${ }^{1}$. About one third of whole population of world are infected with HBV. of them about $5 \%$ become chronic carrier and one fourth of this carriers develop serious liver diseases as chronic hepatitis, cirrhosis and hepatocellular carcinoma (HCC). Yearly HBV related documented death in the world is about $780000^{2}$. In our country prevalence of $\mathrm{HBV}$ is about $5.5 \%$ in general population ${ }^{3}$.

Another virus Hepatitis C (HCV) usually cause asymptomatic acute hepatitis and also cause end stage liver disease like chronic hepatitis, cirrhosis and $\mathrm{HCC}^{4}$. Estimated global prevalence of $\mathrm{HCV}$ is $2.5 \%$ with 118.9 million patients having RNA positive. In Asia the prevalence is $2.8 \%$ and it constitutes more than $60 \%$ of total patients in the world ${ }^{5}$. In Asia HCV RNA positive cases are about 71.9 million ${ }^{5}$. Prevalence of HCV in Bangladesh is about $0.88 \% 6$.

Human immunodeficiency virus (HIV) and its related disease Acquired immunodeficiency syndrome (AIDS) are another major global public health issue. In 2018 about 37.9 million people were infected with HIV of which 1.7 million were children ${ }^{7}$. In our country prevalence of HIV / AIDS is about $0.01 \%$ and it is lower than our neighbouringcountries Nepal and India ${ }^{8}$.

All these three blood- borne viruses, HBV, HCV and HIV, spread through unsafe use of therapeutic injections, blood transfusion, mother to child transmission, unsafe sexual practice, razor sharing or barber shop shaving and beauty treatments including tattoing, ear-nose piercing, manicure and pedicure ${ }^{9,10}$.

Razor sharing and shaves from barbers are important risk factor of blood borne virus transmission. In many countries of Asia and Africa, people use to have shaving at barber shop and roadside barber which is a route of virus transmission ${ }^{11}$. 
In Bangladesh, people, although statistics is not available, go to barber shops for shaving. And in villages people go to roadside barber on Hat day, but this tradition is gradually decreasing. In developed countries, barbers have to get institutional training before working as a professional. But till now in our country there is no system of such training. It mostly appears to be profession of a specific group of people in our country. Any one even without minimum educational background, one can work as barber being trained from seniors and sometimes from family members. So their knowledge regarding transmission of these viruses seems to be inadequate. With this background, this study was designed to see the knowledge, attitude and practice of barbers of Sylhet, Bangladesh regarding transmission of these viruses.

\section{Materials and Methods}

Barber shops of within city and adjacent areas outside city were selected randomly and workers were then interviewed by trained interviewers at their shops. Their demographical information and answers to different questions were recorded in predesigned data sheets. Barbers, not willing to take part in the study, were excluded. Positive answers as blood transfusion, contaminated syringe sharing, contaminated shaving instruments and unsafe sex as mode of transmission of these viruses were taken as correct answeres. Answers mentioning at least one of these as mode transmission were considered as partially correct. And answers other than these were taken as wrong.

\section{Statistical analysis}

Data was analysed using statistical Package for Social Science( SPSS) version 20 (Inc., Chicago, IL USA). Mean and standard deviation and percentages were calculated for continuous data. Comparisons of variables to see difference were done by Chi-square test for categorical data. And $\mathrm{P}$ value $<0.05$ was taken as significant.

\section{Results}

Total 403 barbers were interviewed. All of them were male. Age of them varied from 14 years to 69 years (mean 27.11 and SD 9.34). Among them 343 (85.1\%) and 60 $(14.9 \%)$ were working in city and adjacent areas outside city respectively (table I).

Table I: Demographic profile of barbers.

\begin{tabular}{l|c|c}
\hline & Number & Percentage \\
\hline Total & 403 & 100 \\
Working in city & 343 & 85.1 \\
Working outside of city & 60 & 14.9 \\
married & 203 & 50.4 \\
unmarried & 200 & 49.6 \\
Age up to 20 years & 102 & 25.3 \\
Age 21-30 years & 206 & 51.1 \\
Age 31-40 years & 58 & 14.4 \\
Age 41 and above & 37 & 9.2 \\
\hline
\end{tabular}

\begin{tabular}{l|c|c}
\hline & Number & Percentage \\
\hline Education - Illiterate & 49 & 12.2 \\
Class one to class Five & 183 & 45.4 \\
Class six to class eight & 121 & 30.0 \\
Class nine to SSC & 40 & 9.9 \\
Class 11 and above & 10 & 2.5 \\
Income up to 5000 taka/month & 54 & 13.4 \\
5001 to 10,000 taka/month & 189 & 46.9 \\
10001 to 15000 taka/month & 111 & 27.5 \\
Above 15,000 taka/month & 49 & 12.2 \\
\hline
\end{tabular}

In this series $49(12.2 \%)$ were illiterate and $183(45.4 \%)$ had educational background from class one to class five level. Only $10(2.5 \%)$ had education background above secondary level. Income of them varied from 2,000 to 50,000 taka per month (mean 11174.94 and SD 6050.14). All barbers working outside city $(60 ; 14.9 \%)$ had income within 2000 to 5000 taka range and 189 (46.9\%) had income within $6-10$ thousand taka per month range. Age of $206(51.10 \%)$ were within 21 to 30 years and 102 (25.3\%) were below 21 years. In this series, 101 (25.1\%), $96(23.8 \%)$ and $156(38.7 \%)$ knew that saloon instrument could transmit HBV, HCV and HIV respectively (table II). Blood transfusion could transmit HBV, HCV and HIV was known to $136(33.7 \%), 129(32.00 \%)$ and $247(61.30 \%)$ of our respondents respectively (table II).

Table II: Knowledge of viruses.

\begin{tabular}{|c|c|c|c|c|c|c|c|c|c|}
\hline Transmission & \multicolumn{3}{|c|}{ Hepatitis B } & \multicolumn{3}{|c|}{ Hepatitis C } & \multicolumn{3}{|c|}{ HIV } \\
\hline Sources & $\begin{array}{l}\text { Yes } \\
(\%)\end{array}$ & $\begin{array}{l}\text { No } \\
(\%)\end{array}$ & \begin{tabular}{|c|} 
No \\
idea(\%)
\end{tabular} & $\begin{array}{l}\text { Yes } \\
(\%)\end{array}$ & $\begin{array}{l}\text { No } \\
(\%)\end{array}$ & $\begin{array}{l}\text { No } \\
\text { idea }\end{array}$ & $\begin{array}{l}\text { Yes } \\
(\%)\end{array}$ & $\begin{array}{l}\text { No } \\
(\%)\end{array}$ & \begin{tabular}{|c|} 
No \\
idea(\%)
\end{tabular} \\
\hline Water & $\begin{array}{c}66 \\
(16.4)\end{array}$ & $\begin{array}{c}35 \\
(8.7)\end{array}$ & $\begin{array}{c}302 \\
(74.9)\end{array}$ & $\begin{array}{c}60 \\
(14.9)\end{array}$ & $\begin{array}{c}37 \\
(9.2)\end{array}$ & $\begin{array}{c}306 \\
(75.9)\end{array}$ & \begin{tabular}{|c|}
82 \\
$(20.3)$
\end{tabular} & $\begin{array}{c}127 \\
(31.5)\end{array}$ & $\begin{array}{c}194 \\
(48.1)\end{array}$ \\
\hline Food & $\begin{array}{c}43 \\
(10.7)\end{array}$ & $\begin{array}{c}51 \\
(12.7)\end{array}$ & $\begin{array}{c}309 \\
(76.7)\end{array}$ & $\begin{array}{c}40 \\
(9.9)\end{array}$ & $\begin{array}{c}50 \\
(12.4)\end{array}$ & $\begin{array}{c}313 \\
(77.7)\end{array}$ & $\begin{array}{c}59 \\
(14.6)\end{array}$ & $\begin{array}{c}147 \\
(36.5)\end{array}$ & $\begin{array}{c}197 \\
(48.9)\end{array}$ \\
\hline Tatto & $\begin{array}{c}41 \\
(10.2)\end{array}$ & $\begin{array}{c}13 \\
(3.2)\end{array}$ & $\begin{array}{c}349 \\
(86.6)\end{array}$ & $\begin{array}{c}40 \\
(9.9)\end{array}$ & $\begin{array}{c}11 \\
(2.7)\end{array}$ & $\begin{array}{c}352 \\
(87.3)\end{array}$ & $\begin{array}{c}63 \\
(15.6)\end{array}$ & $\begin{array}{c}53 \\
(13.2)\end{array}$ & $\begin{array}{c}287 \\
(71.2)\end{array}$ \\
\hline $\begin{array}{l}\text { Ear/nose } \\
\text { prick }\end{array}$ & $\begin{array}{c}51 \\
(12.7)\end{array}$ & $\begin{array}{c}13 \\
(3.2)\end{array}$ & $\begin{array}{c}339 \\
(84.1)\end{array}$ & $\begin{array}{c}45 \\
(11.2)\end{array}$ & $\begin{array}{c}14 \\
(3.5)\end{array}$ & $\begin{array}{c}344 \\
(85.4)\end{array}$ & \begin{tabular}{|c}
84 \\
$(20.8)$
\end{tabular} & $\begin{array}{c}61 \\
(15.1)\end{array}$ & $\begin{array}{c}258 \\
(64.0)\end{array}$ \\
\hline $\begin{array}{l}\text { Saloon } \\
\text { instrument }\end{array}$ & $\begin{array}{c}101 \\
(21.1)\end{array}$ & $\begin{array}{c}14 \\
(3.5)\end{array}$ & $\begin{array}{c}288 \\
(71.5)\end{array}$ & $\begin{array}{c}96 \\
(23.8)\end{array}$ & $\begin{array}{c}15 \\
(3.7)\end{array}$ & $\begin{array}{c}292 \\
(72.5)\end{array}$ & $\begin{array}{c}156 \\
(38.7)\end{array}$ & $\begin{array}{c}50 \\
(12.4)\end{array}$ & $\begin{array}{c}197 \\
(48.9)\end{array}$ \\
\hline $\begin{array}{l}\text { Surgical } \\
\text { instrument }\end{array}$ & $\begin{array}{c}67 \\
(16.6)\end{array}$ & $\begin{array}{c}16 \\
(4.0)\end{array}$ & $\begin{array}{c}320 \\
(79.4)\end{array}$ & $\begin{array}{c}64 \\
(15.9)\end{array}$ & $\begin{array}{c}16 \\
(4.0)\end{array}$ & $\begin{array}{c}323 \\
(80.1)\end{array}$ & \begin{tabular}{|c|}
126 \\
$(31.3)$
\end{tabular} & $\begin{array}{c}44 \\
(10.9)\end{array}$ & $\begin{array}{c}233 \\
(57.8)\end{array}$ \\
\hline $\begin{array}{l}\text { Dental } \\
\text { procedure }\end{array}$ & $\begin{array}{c}47 \\
(11.7)\end{array}$ & $\begin{array}{c}15 \\
(3.7)\end{array}$ & $\begin{array}{c}341 \\
(84.6)\end{array}$ & $\begin{array}{c}40 \\
(9.9)\end{array}$ & $\begin{array}{c}16 \\
(4.0)\end{array}$ & $\begin{array}{c}347 \\
(86.1)\end{array}$ & $\begin{array}{c}87 \\
(21.6)\end{array}$ & $\begin{array}{c}47 \\
(11.7)\end{array}$ & $\begin{array}{c}269 \\
(66.7)\end{array}$ \\
\hline $\begin{array}{l}\text { blood } \\
\text { transfusion }\end{array}$ & $\begin{array}{c}136 \\
(33.7)\end{array}$ & $\begin{array}{c}2 \\
(0.5)\end{array}$ & $\begin{array}{c}265 \\
(65.8)\end{array}$ & $\begin{array}{c}129 \\
(32.0)\end{array}$ & $\begin{array}{c}2 \\
(0.5)\end{array}$ & $\begin{array}{c}272 \\
(67.5)\end{array}$ & $\begin{array}{c}247 \\
(61.3)\end{array}$ & $\begin{array}{c}21 \\
(5.2)\end{array}$ & $\begin{array}{c}135 \\
(33.5)\end{array}$ \\
\hline $\begin{array}{l}\text { Syringe } \\
\text { sharing }\end{array}$ & $\begin{array}{c}131 \\
(32.5)\end{array}$ & $\begin{array}{c}5 \\
(1.2)\end{array}$ & $\begin{array}{c}257 \\
(66.3)\end{array}$ & $\begin{array}{c}127 \\
(31.5)\end{array}$ & $\begin{array}{c}4 \\
(1.0)\end{array}$ & $\begin{array}{c}272 \\
(67.5)\end{array}$ & $\begin{array}{c}278 \\
(69.0)\end{array}$ & $\begin{array}{c}4 \\
(1.0)\end{array}$ & $\begin{array}{c}121 \\
(30.0)\end{array}$ \\
\hline $\begin{array}{l}\text { Drug } \\
\text { addiction }\end{array}$ & $\begin{array}{c}113 \\
(28.0)\end{array}$ & $\begin{array}{c}3 \\
(0.7)\end{array}$ & $\begin{array}{c}287 \\
(71.2)\end{array}$ & $\begin{array}{c}103 \\
(25.6)\end{array}$ & $\begin{array}{c}3 \\
(0.7)\end{array}$ & $\begin{array}{c}297 \\
(73.7)\end{array}$ & \begin{tabular}{|c|}
257 \\
$(63.8)$
\end{tabular} & $\begin{array}{c}1 \\
(0.2)\end{array}$ & $\begin{array}{c}145 \\
(36.0)\end{array}$ \\
\hline Unsafe sex & $\begin{array}{c}166 \\
(41.2)\end{array}$ & $\begin{array}{c}8 \\
(2.0)\end{array}$ & $\begin{array}{c}229 \\
(56.8)\end{array}$ & $\begin{array}{c}158 \\
(39.2)\end{array}$ & $\begin{array}{c}8 \\
(2.0)\end{array}$ & $\begin{array}{c}237 \\
(58.8)\end{array}$ & $\begin{array}{c}317 \\
(78.7)\end{array}$ & $\begin{array}{c}1 \\
(0.2)\end{array}$ & $\begin{array}{c}85 \\
(21.1)\end{array}$ \\
\hline Outcome & & & & & & & & & \\
\hline
\end{tabular}




\begin{tabular}{|l|c|c|c|c|c|c|c|c|c|}
\hline Total cure & $\begin{array}{c}62 \\
(15.4)\end{array}$ & $\begin{array}{c}66 \\
(16.4)\end{array}$ & $\begin{array}{c}275 \\
(68.2)\end{array}$ & $\begin{array}{c}61 \\
(15.1)\end{array}$ & $\begin{array}{c}60 \\
(14.9)\end{array}$ & $\begin{array}{c}282 \\
(70.0)\end{array}$ & $\begin{array}{c}118 \\
(29.3)\end{array}$ & $\begin{array}{c}162 \\
(40.2)\end{array}$ & $\begin{array}{c}123 \\
(30.5)\end{array}$ \\
\hline $\begin{array}{l}\text { CLD and } \\
\text { dealh }\end{array}$ & $\begin{array}{c}43 \\
(10.7)\end{array}$ & $\begin{array}{c}3 \\
(0.7)\end{array}$ & $\begin{array}{c}357 \\
(88.6)\end{array}$ & $\begin{array}{c}35 \\
(8.7)\end{array}$ & $\begin{array}{c}4 \\
(1.0)\end{array}$ & $\begin{array}{c}364 \\
(90.0)\end{array}$ & $\begin{array}{c}78 \\
(19.4)\end{array}$ & $\begin{array}{c}30 \\
(7.4)\end{array}$ & $\begin{array}{c}295 \\
(73.2)\end{array}$ \\
\hline $\begin{array}{l}\text { Cancer and } \\
\text { death }\end{array}$ & $\begin{array}{c}36 \\
(8.9)\end{array}$ & $\begin{array}{c}27 \\
(6.7)\end{array}$ & $\begin{array}{c}340 \\
(84.4)\end{array}$ & $\begin{array}{c}31 \\
(7.7)\end{array}$ & $\begin{array}{c}26 \\
(6.5)\end{array}$ & $\begin{array}{c}346 \\
(85.9)\end{array}$ & $\begin{array}{c}167 \\
(41.4)\end{array}$ & $\begin{array}{c}24 \\
(6.0)\end{array}$ & $\begin{array}{c}212 \\
(52.6)\end{array}$ \\
\hline AIDs & & & & & & & $\begin{array}{c}262 \\
(65.0)\end{array}$ & $\begin{array}{c}6 \\
(1.5)\end{array}$ & $\begin{array}{c}135 \\
(33.5)\end{array}$ \\
\hline
\end{tabular}

In this study 131 (32.5\%), 127 (31.50\%) and 278 (69.0\%) barbers believed that contaminated syringe sharing could transmit HBV, HCV and HIV respectively. In this study $166(41.2 \%), 158(39.2 \%)$ and $317(78.70 \%)$ barbers respectively believed that unsafe sex could transmit HBV, $\mathrm{HCV}$ and HIV. It is also seen that knowledge regarding transmission of HIV was better. In this series $84(20.84 \%)$ and $99(24.57 \%)$ barbers' answers regarding transmission of this three viruses were correct and partially correct respectively.

Only $43(10.7 \%)$ and $35(8.7 \%)$ of barbers respectively knew that HBV and HCV infection might lead to cirrhosis and HCC and death (table II). On the other hand 78(19.4\%) barbers of this series know that HIV infection leads to death.

Their main source of knowledge were radio and television (322; 79.90\%) and news paper (166; 41.2\%) (table III).

Table III: Source of knowledge for barbers.

\begin{tabular}{l|c|c}
\hline Sources & Yes (\%) & No (\%) \\
\hline Radio and television & $322(79.9)$ & $81(20.1)$ \\
Newspaper & $166(41.2)$ & $237(58.8)$ \\
Hospital & $60(14.9)$ & $343(85.1)$ \\
NGO workers & $14(3.5)$ & $389(96.5)$ \\
Health Workers & $46(11.4)$ & $357(88.6)$ \\
Books & $34(8.4)$ & $369(91.6)$ \\
Own Idea & $223(55.3)$ & $180(44.7)$ \\
\hline
\end{tabular}

But role of hospital, health workers, Nongovernment Organisations (NGO) workers, and books for dissemination of knowledge to them regarding transmission of viruses was minimum. In this group, 318 (78.9\%) thought that testing and treatment measure should be taken against these viruses.

Again 49 (12.2\%) who were vaccinated for HBV thought vaccination could prevent these viral diseases. In this series, 84 (20.8\%), 42 (10.4\%), 47 (11.7\%), 18 (4.5\%) and $07(1.7 \%)$ respectively had history of surgery, blood transfusion, ear or nose prick, tattoing and drug addiction (table IV).
Table IV: Personal history and practice.

\begin{tabular}{|l|c|c|c|c|}
\hline & Yes & Percentage & No & Percentage \\
\hline Vaccinated for HBV & 49 & 12.2 & 354 & 87.8 \\
\hline Drug addiction & 7 & 1.7 & 396 & 98.3 \\
\hline H/o blood transfusion & 42 & 10.4 & 361 & 89.6 \\
\hline Need surgery & 84 & 20.8 & 319 & 79.2 \\
\hline Has tattoo & 18 & 4.5 & 385 & 95.5 \\
\hline Has ear - nose prick & 47 & 11.7 & 356 & 88.3 \\
\hline Practice at saloon & & & & \\
\hline Hand washing before new client & 376 & 93.3 & 27 & 6.7 \\
\hline Sterilize instruments & 230 & 57.1 & 173 & 42.9 \\
\hline $\begin{array}{l}\text { Washes with tap water without } \\
\text { sterilisation }\end{array}$ & 157 & 39.0 & 246 & 61.04 \\
\hline Just wipe instrument with paper & 16 & 3.9 & & \\
\hline Use separate blade for every client & 401 & 99.5 & 2 & 0.5 \\
\hline Use antiseptics & 398 & 98.8 & 5 & 1.2 \\
\hline Dispose blades to garbage bin & 371 & 92.1 & $32^{*}$ & 7.9 \\
\hline
\end{tabular}

*they dispose blades improperly

In these group, $376(93.3 \%)$ respondents told that they washed hands before serving every new clients, 230 $(57.1 \%)$ sterilise instruments with chemicals, and 157 $(39.0 \%)$ washed instrument with tap water before working with new customer. They uses savlon (mixture of cetrimide and chlorhexidine) for sterilisation. In this series 401 $(99.5 \%)$ uses separate blades for every customers and 398 $(98.8 \%)$ provide antiseptic cream (usually savlon) for skin injuries. Most of respondents disposes blades in garbage.

Answers of barbers were regarding transmission of all three viruses significantly differed with educational background. Answers of barbers regarding transmission of HIV virus also significantly differed with age, income and marital status (table V).

Table V: Relation of variables.

\begin{tabular}{|c|c|c|c|c|c|c|}
\hline & & Variables & $\begin{array}{c}\text { Correct } \\
\text { Answer } 84(\%)\end{array}$ & $\begin{array}{c}\text { Partially } \\
\text { Correct } 99(\%)\end{array}$ & $\begin{array}{c}\text { Wrong } 220 \\
(\%)\end{array}$ & \begin{tabular}{|c|}
$P$ \\
value
\end{tabular} \\
\hline \multirow[t]{14}{*}{ HBV } & Age group & Up to $20 \mathrm{y}(102)$ & $17(16.66)$ & $21(20.59)$ & $64(62.74)$ & \multirow[t]{4}{*}{0.695} \\
\hline & & $21-30$ y $(206)$ & $46(22.33)$ & $52(24.24)$ & $108(52.43)$ & \\
\hline & & $31-40$ y $(58)$ & $13 \quad(22.41)$ & $16(27.58)$ & $29(50.00)$ & \\
\hline & & Above 40 y (37) & $\begin{array}{ll}8 & (21.62) \\
\end{array}$ & $10(27.03)$ & $19(51.35)$ & \\
\hline & Income & Up to $5000(54)$ & $\begin{array}{ll}9 & (16.66) \\
\end{array}$ & $21(38.89$ & 2444.44 & \multirow[t]{4}{*}{0.12} \\
\hline & & $5001-10000(189$ & $35(18.52)$ & $42(22.22)$ & $112(59.26)$ & \\
\hline & & $10001-15000(111)$ & $28(25.22)$ & $23(20.72)$ & $60(54.05)$ & \\
\hline & & $>15000(49)$ & $12(24.49)$ & $13(26.53)$ & $24(48.98)$ & \\
\hline & \begin{tabular}{|l|} 
Education \\
\end{tabular} & Class 0 to five(232) & $37(15.95)$ & $68(29.31)$ & $127(54.74)$ & \multirow[t]{4}{*}{0.012} \\
\hline & & Class 6-8 (121) & $29(23.97)$ & $21(17.35)$ & $71(58.68)$ & \\
\hline & & Class 9-10 (40) & $14(35.00)$ & $7(17.50)$ & $19(47.50)$ & \\
\hline & Marital status & $\geq$ Class $11(10)$ & $4 \quad(40.00)$ & $3(30.00)$ & $3(30.00)$ & \\
\hline & & married 203 & $43(21.18)$ & $53(26.11)$ & $107(52.71)$ & \multirow[t]{2}{*}{\begin{tabular}{|l|l}
0.71 \\
\end{tabular}} \\
\hline & & single 200 & $41(20.50)$ & $46(23.00)$ & 11356.50 & \\
\hline \multirow[t]{14}{*}{$\mathrm{HCV}$} & Age group & Up to $20 \mathrm{y}(102)$ & $17(16.67)$ & $21(20.59)$ & $64(62.74)$ & \multirow[t]{4}{*}{0.695} \\
\hline & & $21-30$ y $(206)$ & $43(20.87)$ & $47(22.81)$ & $116(56.31)$ & \\
\hline & & $31-40$ y $(58)$ & $12(20.69)$ & $15(25.86)$ & $31(53.44)$ & \\
\hline & & Above 40 y (37) & $7(18.92)$ & $10(27.03)$ & $20(54.05)$ & \\
\hline & Income & Up to $5000(54)$ & $9(16.66)$ & $20(37.04)$ & $25(46.29)$ & \multirow[t]{4}{*}{0.184} \\
\hline & & $5001-10000(189)$ & $34(17.99)$ & $41(21.69)$ & $114(60.31)$ & \\
\hline & & $10001-15000(111)$ & $27(24.32)$ & $21(18.92)$ & $63(56.76)$ & \\
\hline & & $>15000(49)$ & $9(18.37)$ & $11(22.45)$ & $29(59.18)$ & \\
\hline & \begin{tabular}{|l|} 
Education \\
\end{tabular} & Class 0 to five(232) & $36(15.52)$ & $37(15.95)$ & $129(55.60)$ & \multirow[t]{4}{*}{0.011} \\
\hline & & Class 6-8 (121) & $27(22.31)$ & $17(14.05)$ & $77(63.63)$ & \\
\hline & & Class 9-10 (40) & $12(30.0)$ & $7(17.50)$ & $21(52.5)$ & \\
\hline & & $\geq$ Class $11(10)$ & $4 \quad(40.00)$ & $2(20.0)$ & $4(40.00)$ & \\
\hline & Marital status & Married 203 & $39(19.21)$ & $48(23.64)$ & $116(57.14)$ & \multirow[t]{2}{*}{0.955} \\
\hline & & Single 200 & $40(20.0)$ & $45(22.50)$ & $115(57.50)$ & \\
\hline \multirow[t]{14}{*}{ HIV } & \begin{tabular}{|l|} 
Age group \\
\end{tabular} & Up to $20 \mathrm{y}(102)$ & $23(22.55)$ & $46(45.10)$ & $33(32.35)$ & \multirow[t]{4}{*}{0.000} \\
\hline & & $21-30$ y $(206)$ & $81(39.32)$ & $102(49.51)$ & $23(11.16)$ & \\
\hline & & $31-40$ y $(58)$ & $24(41.38)$ & $23(39.65)$ & $11(18.96)$ & \\
\hline & & Above 40 y (37) & $12(32.43)$ & $13(35.13)$ & $12(32.43)$ & \\
\hline & Income & Up to $5000(54)$ & $11(20.37)$ & $23(42.59)$ & $20(37.04)$ & \multirow[t]{4}{*}{0.002} \\
\hline & & $5001-10000(189)$ & $60(31.74)$ & $92(48.68)$ & 37 (19.57) & \\
\hline & & $10001-15000(111)$ & $44(39.64)$ & $52(46.84)$ & $15(13.51)$ & \\
\hline & & $>15000(49)$ & $25(51.02)$ & $17(34.69)$ & $7(14.28)$ & \\
\hline & \begin{tabular}{|l|} 
Education \\
\end{tabular} & Class 0 to five(232) & $71(30.60)$ & $105(45.26)$ & $56(24.14)$ & \multirow[t]{4}{*}{0.003} \\
\hline & & class 6-8 (121) & $40(33.06)$ & $59 \quad(48.76)$ & $22(18.18)$ & \\
\hline & & Class 9-10 (40) & $23(57.5)$ & $16(40.0)$ & $1(2.50)$ & \\
\hline & & $\geq$ Class $11(10)$ & $\begin{array}{ll}6 & (60.0) \\
\end{array}$ & $\begin{array}{ll}4 & (40.0) \\
\end{array}$ & 0 & \\
\hline & Marital status & married 203 & $70(34.48)$ & $104(51.23)$ & $29(14.28)$ & \multirow[t]{2}{*}{0.013} \\
\hline & & single 200 & $70(35.0)$ & $80(40.00)$ & $50(25.00)$ & \\
\hline
\end{tabular}




\section{Discussion}

This study was done to see the knowledge of barbers regarding transmission of $\mathrm{HBV}, \mathrm{HCV}$ and $\mathrm{HIV}$ and their practice in shops in Sylhet, Bangladesh. In this series, all respondents were male. In our country usually males are involved in barbering. Mostly this profession runs in family from generation to generation. And Beauty parlour workers are usually female. our report was consistent with report from Sudan, where workers at barber shop are usually male ${ }^{12}$. In this study more than half of respondents had either none or minimum institutional education. Educational level of them is better than that of Pakistan ${ }^{13,14}$, but worse than that of Sudan ${ }^{12}$ and India ${ }^{15}$, Ghana ${ }^{16}$. Age of more than $50 \%$ of barbers were within 21 to 30 years which is consistent with report from Pakistan ${ }^{13}$. Mean age of our respondents was similar to that of barbers in Sudan ${ }^{12}$. Income of our respondents were similar to income of barbers in Pakistan $^{13}$. It is to mention that income of barbers working outside the city in our series were low. About one third of our respondents had proper knowledge about transmission of HBV and HCV. And only one fourth of our respondents believed that contaminated shaving instruments can transmit $\mathrm{HBV}$ and $\mathrm{HCV}$. But more than $90 \%$ barbers in Italy $^{17}$ are aware about the route of transmission of HBV and HCV. Only about $10 \%$ of series know that HBV and $\mathrm{HCV}$ can cause chronic hepatitis, cirrhosis and HCC. Knowledge of respondents was better than that of barbers of Ghana ${ }^{16}$ while poorer than that of barbers of Pakistan ${ }^{14}$. Vaccination rate in our series was slightly higher than that in Pakistan ${ }^{14}$.

It is to mention that prevalence of $\mathrm{HBV}$ is also higher among barbers in $\mathrm{China}^{18}$ and Morocco $^{19}$. But in our country such report is not available. In Iran about $1.1 \%$ of barbers were seropositive for $\mathrm{HCV}{ }^{20}$. One study from Turkey showed presence of HBV DNA in $6.6 \%$ of used razor blades by semi nested PCR method ${ }^{21}$. It favours the transmission of blood borne viruses due to micro injury of skin during shaving.

Regarding HIV more than two third of respondents were aware of transmission through blood transfusion, syringe sharing and unsafe sex. But about $38 \%$ of respondents were aware of transmission through contaminated shaving instruments which is just better than the report from Ethiopia $^{22}$, but far lower than report from Italy ${ }^{17}$. Education and socio-cultural difference can influence this differences. One fifth of our respondents were aware of death related to HIV and AIDS which is far lower than awareness among barbers in Italy $^{17}$ and Ethiopia ${ }^{22}$. Regarding prevention, most of our respondents opine for testing and treatment. While one third were in favour of vaccination.

In our study almost all respondents use separate blades for each and every new customers. This practice is far better that report from Italy $^{17}$. Again $93 \%$ of our respondents washes hands before working with new client. But slightly more than half our barbers sterilises instruments with chemicals before using on new customer. And 43\% wash their instrument with tap water, and very small group uses to wipe instrument with paper only in between two new customers. They have no good idea regarding duration required for chemical sterilisation and other important methods of sterilistion as autoclaving or use of ultraviolet rays. Micro trauma during shaving may contaminate shaving instruments including razor blades. Inadequate sterilisation of instruments thus lead viral transmission from one customer to another. Regarding this practice, our respondents were far behind the practice in Italy ${ }^{17}$ and Ethiopia $^{22}$. Education and social and cultural difference could explain this difference.

Our respondents usually do not wear gloves which are similar to the practice in India ${ }^{15}$, Ethiopia ${ }^{22}$ and Pakistan ${ }^{23}$ Most of our respondents use to dispose used blades in garbage which increase health risk to the garbage handlers and cleaners and similar practice is reported from Sudan ${ }^{12}$, and Ghana ${ }^{16}$.

From this study it is evident that level of education influence the knowledge about transmission of blood borne viral infection from one person to another. One study from Pakistan reported that educational intervention improved the awareness among both community people and professionals regarding transmission of HIV/AIDS ${ }^{24}$. So programmed dissemination of knowledge to our barbers about transmission of blood borne viral diseases, its precaution, health hazards related to profession for them and their customers, need and methods of proper sterilisation of instruments, use of gloves, proper disposal of sharp instrument can improve their knowledge, change their practice and attitude.

\section{Conclusion}

Knowledge of our barbers regarding transmission of $\mathrm{HBV}$, $\mathrm{HCV}$ and HIV is incomplete and inadequate. Good number of them do not sterilize instruments at all or sterilize improperly which is dangerous. So in addition to institutional education, structured training for barbers regarding their professional skill and health related affairs may improve their services along with decrease of transmission of viral diseases and related health hazards for them and also the community.

\section{Conflict of Interest: None.}

\section{Acknowledgement}

We are grateful to Department of Statistics, Shahjalal University of Science and Technology, Sylhet, Bangladesh for help in data processing.

\section{References}

1. Franco E, Bagnato B, Marino MG, Meleleo C, Serino L, Zaratti L. Hepatitis B: epidemiology and prevention in developing countries. World J Hepatol. 2012; 4: 74-80.

https://doi.org/10.4254/wjh.v4.i3.74

https://doi.org/10.4254/wjh.v4.i3.68

2. Sharma SK, Saini N, Chwla Y. Hepatitis Virus: Inactive carriers. Virol J. 2005; 2: 82.

https://doi.org/10.1186/1743-422X-2-82

PMid:16191199 PMCid:PMC1253537

3. Mahtab MA, Rahman S, Karim MF. Epidemiology of hepatis B virus in Bangladeshi general population. Hepatobiliary Pancreatic Dis Int. 2008; 7(6): 596-600. 
4. Grebely J, Dore GJ. What is killing people with hepatitis C virus infection? Semin Liver Dis. 2011; 31: 331-9. Epub 2011 Dec 21

https://doi.org/10.1055/s-0031-1297922

PMid:22189973

5. Petruzziello A, Marigliano S, Loquercio G, Cozzolino A, Cacciapuoti C. Global epidemiology of hepatitis $\mathrm{C}$ virus infection: An up-date of the distribution and circulation of hepatitis C virus genotypes. World J Gastroenterol. 2016 Sep 14; 22(34):7824-40.

https://doi.org/10.3748/wjg.v22.i34.7824

PMid:27678366 PMCid:PMC5016383

6. Al-Mahtab, M., Rahman, S., Karim, F., et al. Epidemiology of Hepatitis C Virus in Bangladeshi General Population. Bangabandhu Sheikh Mujib Medical University Journal. 2(1), 14-17.

https://doi.org/10.3329/bsmmuj.v2i1.3705

7. UNAIDS (2019); AIDinfo.unaids.org

8. Faruk O, Begum N, Rana S. Trends of HIV/AIDS epidemic and awareness levels in Bangladesh. International Journal on Data Science and technology. 2017(Dec); 3(6): 56-65.

https://doi.org/10.11648/j.ijdst.20170306.11

9. World Health Organisation. Unsafe injection practices having serious large scale consequences. Press Releases WHO. 2000; 14: 1-20.

10. Marino A, Mele A, Tosti ME. Role of Beauty treatment in the spread of parenteraly transmitted viruses in Italy. J Med Virol. 2004; 74: 216-20.

https://doi.org/10.1002/jmv.20182

PMid: 15332269

11. Khaliq AA, Smego RA. Barber shaving and blood-borne disease transmission in developing countries. S Afro Med J. 2005; 95: 94-6.

12. Eltayeb NH, Mudawi HMY. Knowledge and practice of barbers regarding transmission of blood-borne virueses in Khartoum state. Annals of tropical Medicine and Public Health. 2013; 6(1): 80-83.

http://www.atmph.org/text.asp?2013/6/1/80/115201

https://doi.org/10.4103/1755-6783.115201

13. Jokhis AH, Bhatt TA, Menon MS. Knowledge, attitude and practice of barbers about hepatitis $\mathrm{B}$ and $\mathrm{C}$ transmission in Hederabad, Pakistan. Eastern mediterranean Health Journal. 2010; 6(10): 1079-84. http://applications.emro.who.int/emhj/V16/10/16_10_2010_1079_1184.pdf

https://doi.org/10.26719/2010.16.10.1079

PMid:21222425

14. Waheed Y, Saeed U, Safi SZ, Chaudhry WN, Qadri I. Awareness and risk factors associated with barbers in transmission of Hepatitis B and C from Pakistani population: Barber's role in viral transmission. 2010 (July) Asian biomedicine 4(3):435-442. 10.2478/abm-2010-0053

https://doi.org/10.2478/abm-2010-0053
15. Khandait DW, Ambadekar NN, Vasudeo ND. Knowledge and practice about HIV transmission among barbers of Nagpur city. Indian J Med Sci. 1999; 53(4): 167-71.

16. Mutocheluh M and Kwarteng K. Knowledge and occupational hazards of barbers in transmission of hepatitis B and C was low in Kumasi Ghana. Pan Afr Med J. 2015; 20: 260-66.

https://doi.org/10.11604/pamj.2015.20.260.4138

\section{PMid:26161183 PMCid:PMC4484403}

17. Amodio E, DiBeneDetto MA, Gennaro L, Madia CM, Romano N. Knowledge, attitude and risk of HIV, HBV and $\mathrm{HCV}$ infections in hairdressers of Palermo city (South Italy). European Journal of Public Health. 2009; 20(4): 433-37.

https://doi.org/10.1093/eurpub/ckp178

PMid: 19892853

18. She SL, Shi LY, Wu YJ, Li ZZ, Zheng CZ, Wu YP, et al. A seroepidemiologycal study of hepatitis B virus infection among barbers in Huangshi city, Hubei, China. MicrobiolImmunol. 1988; 32(2): 229-33.

https://doi.org/10.1111/j.1348-0421.1988.tb01382.x

PMid:3374409

19. Belbacha I, Cherkaoui I, Akrim M, Dooley KE, Aouad REI. Seroprevalence of Hepatitis B and C amongbarbers and their clients in Rabat region of Morocco. Eastern Mediterranean Health Journal. 2011; 17 (12):911-9.

http://applications.emro.who.int/emhj/V17/12/17_12 _2011_0911_0919.pdf

https://doi.org/10.26719/2011.17.12.911

PMid:22355943

20. Khairkhah T, Shamsa A, Roohi A. Analysis of knowledge, attitude and prevalence of Hepatitis B and C seromarkers among barbers in Trehran. Hepat Mon. 2016 (Sept); 16(9): e39416

https://doi.org/10.5812/hepatmon.39416

PMid:27822265 PMCid:PMC5090804

21. Eroglu C, Zivlioglu M, Esen S, Sunbul M and Leblebicioglu H. Detection of Hepatitis B Virus in used razor blades by PCR. Hepat Mon. 2010: 10(1): 22-25.

22. Ayano WB. Assessment on knowledge, attitude, and practice with regards to transmission and prevention of HIV? AIDs among barbers and Beauty Salon workers in Hossana Town, South Ethiopia. J ClinDiagn Res. 2017;

23. Januja NZ, Nizamy MA. Knowledge and practice of barbers about hepatis B abd C transmission in Rawalpindi and Islamabad. J Pak Med Assoc. 2004; 54: 116-9.

24. Krishnani MK, Ali FA, Khuwaja AK, Didwai W, Ali BS. Educational intervention among barber to improve their knowledge regarding HIV/AIDS: A pilot study from a South Asian country. J Health PolpulNutr. 2014 (Sept); 32(3): 386-390. 